Peer-Reviewed Article

ISSN: 2162-3104 Print/ ISSN: 2166-3750 Online Volume 7, Issue 4 (2017), pp. 1113-1125

(C) Journal of International Students http://jistudents.org/ doi: $10.5281 /$ zenodo. 1035961

\title{
Providing Culturally Relevant Services for International Black African Collegians in the United States: A Guide for Student Affairs Professionals
}

\author{
Ifeyinwa Uchechi Onyenekwu \\ Rutgers, The State University of New Jersey
}

\begin{abstract}
The experience of international Black African collegians (IBAC) in U.S. higher education has not been adequately investigated, particularly as it relates to understanding the diversity within Black and international student populations. In this manuscript, I offer seven culturally relevant suggestions for student affairs professionals, all of which build on my professional experiences working with IBAC in student affairs as well as my research with Nigerian collegians in U.S. higher education.
\end{abstract}

Keywords: African students, Black collegians, Nigerian, Student Affairs

"Shot in the streets of the United States, raped by police in France, and beat up by citizens in India, man it's tough being Black in this world."

- Angel Mujahid (Mujahid, 2017)

At the time of me writing this article, reports of Black Africans-namely Nigerians - being attacked and killed in India and South Africa are hitting the news circuit (Unah, 2017; Wu, 2017). These unnatural deaths are a reminder that despite ethnicity or national origin Black bodies in the U.S. and around 
the world are being destroyed. As Marc Lamont Hill (2016) pointed out in his book Nobody, "there is an increasingly intense war on the vulnerable" (p. 9), and international Black African collegians (hereafter IBAC) are not exempt from this treatment.

Situated within the current politically charged national climate that is challenging foreign policy and the brutality to Black life, this article explores alternative visions by addressing Black African embodiment in U.S. higher education. With this in mind, the purpose of this article is twofold: (1) to identify the needs and issues that are unique to IBAC in the U.S., and (2) to discuss how student affairs professionals can implement strategies to better serve these students. More specifically, this article is a response to the reality that the experiences of IBAC in U.S. higher education have not been adequately investigated, particularly as it relates to understanding the diversity within this group. Much of the discourse around international students primarily focuses on the experiences of Asian students, while overlooking the experiences of students from other regions (Fries-Britt, George Mwangi, \& Peralta, 2014; Lee \& Rice, 2007). This article attends to the paucity of African experiences in international education literature.

Using my own experience working with IBAC as a student affairs professional and research with Nigerian collegians in U.S. higher education as a point of reference, I provide context in understanding IBAC experiences that adds a practitioner and scholarly lens. What follows is a brief explanation of my two research studies on Nigerian collegians, and seven suggestions for student affairs professionals. While this is not an empirical study, my research provides a deeper understanding of the IBAC lived experiences.

\section{WHY FOCUS ON NIGERIANS?}

It is important to note that Africa is a continent that is made up of over 50 countries with diverse cultures and populations. Nigeria, a country located in West Africa, has the largest Black population in the world. It also has been recorded as having the biggest economy in Africa, and a large sender of students to the U.S. (Institute of International Education [IIE], 2014; Steeves, 2016). With this in mind, Nigerians are a noteworthy demographic to focus on, as it is a growing and understudied Black African population in higher education.

Nigerians in the U.S. are experiencing an African American experience that is unique and distinctive to their Black American peers. They are also graduating college and obtaining degrees at high rates (Capps, 
McCabe, \& Fix, 2012; Kent, 2007). Given their unique and distinctive life experiences as an international and Black student on campus, there is a need for student affairs professionals to learn more about how they can support IBAC. Findings from my two research projects reveal IBAC are confronted with difficult life decisions, and student affairs professionals are in a unique position to help (Patton, Renn, Guido, \& Quaye 2016; Quaye \& Harper, 2014; Reynolds, 2009).

The first project examined how Nigerian college students make meaning of their racial and ethnic identity at a predominantly White institution. Detailed interviews were conducted with 20 Nigerian college students at a Midwestern public research university in spring 2013. Questionnaires were administered to collect socio demographic information. Seven participants reported that they were international students, and five participants were considered transnational as they were born and / or raised in Nigeria.

The second study also employed qualitative research to examine the educational journey of Nigerian returnees with foreign degrees. In December 2015 - January 2016, I surveyed Nigerian returnees in Lagos and Imo State, Nigeria regarding their economic and personal reasons for return. Respondents were asked about their reason for studying overseas and motivation to return to their homeland. A total of 26 valid survey responses were received and 20 in depth semi-structured interviews were conducted. Research was organized in two phases: (1) administering of demographic questionnaires and (2) in depth interviews. The following research questions were examined: What is the educational and career journey of Nigerian returnees? How do Nigerians complicate the brain drain and brain circulation discourse? While the data from these studies do not represent all African international students, it does provide an example and an in depth understanding of potential challenges impacting IBAC. What follows are seven suggestions for student affairs professionals.

\section{Learn About Ethnically Diverse Black Populations}

Student affairs administrators are encouraged by the profession to be knowledgeable of identity development theory (Patton, Renn, Guido, \& Quaye, 2016). Recent research on identity formation (Awokoya, 2012; Balogun, 2009), intraracial diversity (George- Mwangi, 2014), neo racism (Lee \& Opio, 2011), and sense of belonging (Stebleton \& Alexio, 2016) explores ethnically diverse Black students' experiences on U.S. college campuses. The aforementioned work suggests that understanding more about 
the diverse academic and social experiences of IBAC population is essential to improving their opportunities and outcomes.

In addition, it is important to note that Blackness in the U.S. context has political underpinnings (George Mwangi, 2014) and many of these international students are discovering the politics of Blackness through multicultural engagements. In the campus environment, IBAC are being introduced to tropes and stereotypes through formal and informal social interactions with peers, faculty, and administrators. Research shows that these constituents have limited knowledge and exposure to the diversity within the African continent, and often inaccurately compare Black African international students to domestic Black students (Onyenekwu, 2015). Research and media also suggests that higher education professionals perceive Black international students as high academic achievers and "model Black" students (Bennett \& Lutz, 2009; Massey, Mooney, Torres, \& Charles, 2007; Rimer \& Arenson, 2004). Awokoya's (2012) study on Nigerian students illuminates this point. She writes:

Participants discussed how teachers noticed and often commented on behavioral differences between the African and African American students, describing the former as "respectful," "disciplined," and "hard working." Emeka recalled how a teacher differentiated her from her Black peers: "[The teacher said] she could tell that my parents were Africans because I was disciplined and well-behaved . . . and I felt at times that I've been used as kind of that example, that Black example." Likewise, Ngozi reported how a teacher told her, "I could tell immediately that you guys were African kids ... you're not like those Black American kids." Through such passing comments, teachers may not have realized that this may have contributed to African American youths' resentment toward African immigrant youth. (p. 268)

Although the aforementioned quotation pertains to Nigerian participants' K12 experiences, I witnessed firsthand working as a college administrator that IBAC learn and sometimes embrace anti-Black (read: Black American) tropes through similar interactions on campus. Peers, faculty, and staff provided indirect and direct messages that perpetuate negative stereotypes about the academic achievement of Black Americans students. For example, the lack of representation of Black American collegians in engineering programs at predominately white institutions is used as evidence to illustrate that Black 
Americans are not intelligent and/or do not work hard. Such a disturbing and rudimentary understanding ignores the historical legacy of white privilege and institutional racism that has caused significant opportunity gaps that disproportionately disadvantage Black Americans.

Accepting these "comparison compliments" are detrimental to understanding Black Americans and creates intrarcial tensions between IBAC and Black American. To this end, the next section describes how respectability politics manufactures the model minority thesis (see Poon et al., 2016) as a tool that perpetuates cultural racism and intraracial tensions within Black communities. In this context, non-U.S. Black students are being marked as "model" due to perceived behavioral traits and high academic performance.

\section{Avoid Perpetuating the "Model Black" Myth Narrative}

As a higher education researcher, one of my main lines of scholarly inquiry examines how race gets conflated with ethnicity. Not only does this conflating further complicate identity politics for IBAC, but it also promotes tensions between native Black Americans and Africans that are based on myths and lies supporting Whiteness (Onyenekwu, 2015; Pierre, 2004; Poon et al., 2016). In the higher education context, oftentimes

the discursive use of Black / African immigrant ethnic and cultural distinctiveness is predicated and repackaged in ways to perpetuate and reinforce stereotypical understandings of native born and foreign born Black persons. Comparative analysis have reinforced racial myths that devalue Black American culture, and a key aspect of these discourses impedes essential discussions about the complex nature of United States racism and the Black immigrant confrontation with the United States racial hierarchy. (Pierre, 2004, p. 144)

More specifically, IBACs as a minoritized group in the U.S. are used to divert attention away from educational inequalities by propagating the contentious notion that they exhibit cultural values that are appreciated by higher education professionals. Massey, Mooney, Torres and Charles (2007) suggest that some people believe that admissions officers prefer IBACs to Black Americans. In my experience, faculty and staff have expressed mixed feelings regarding IBAC. For some, IBAC are being used to mask the lack of domestic diversity on campus, and are taking the "spots" of domestic Black students. Others see IBACs as model Black students who encompass distinctive cultural attributes such as hard work and academic achievement. Similar to 
other groups of color (i.e. Asian Americans), IBAC are being presented as a "model Black" group through the narrative that serves to reaffirm a racial hierarchy that perpetuates anti-Black racism (Lee \& Opio, 2011; Lee \& Rice, 2007; Pierre, 2004).

\section{Learn from African Student Groups}

Consistent with literature indicating that Black students seek coethnic student organizations for support, IBAC engage in campus clubs and/or organizations as a way of coping with isolation and exclusion on campus (Baber, 2010; Museus, 2008; Onyenekwu, 2015). IBAC join African student groups, which positively influence their identity (Onyenekwu, 2015). Stebleton (2007) suggests in his article on career counseling African students that culturally centered organizations are a great resource for student affairs professionals to connect and learn about diverse African students. It is also important to note that students sometimes mature out of these organizations as they matriculate through college, and pursue more professional student organizations (Onyenekwu, 2015). More specifically, African students are most likely to join and be actively engaged in co-ethnic student organizations during their first and second years of college (Onyenekwu, 2015).

A good way to learn about the rich diversity of African and African diaspora populations is by attending events put on by these student organizations. Stebleton (2007) echoes these sentiments and encourages student affairs professionals "to learn more about African history, culture, and the immigrant experience so that they are better prepared to deal with immigrant students' issues" (p. 304). He also asserts that it is important to examine misconceptions about African students. For instance, he posits that there are three main misconceptions about African students: (1) Africans want to assimilate and break away from their traditions; (2) life is easier in the U.S.; and (3) they want to pursue the American dream (Stebleton, 2007, p. 305). African collegians have their own dreams, and they want these dreams to be acknowledged and fostered. Student affairs professionals should examine their biases and avoid making assumptions about students' needs, issues, and aspirations. Furthermore, student affairs professionals should be cautious with sensationalized media reports about Africa and African populations that focus mainly on poverty, disease, famine, poor infrastructure, and other negative stereotypes; what Nigerian novelist Chimamanda Adichie calls the "danger of the single story" [about Africa] (Adichie, 2009). 


\section{Engage in Anti-racist Marketing of the African Continent}

Professional development and training is needed for student affairs professionals who are interested in working in areas of social justice, diversity, and inclusion. Awokoya (2012) recommends that professionals:

use media as a pedagogical device to deconstruct African stereotypes. Images and discussions on Africa often emphasize political strife, poverty, and disease. Critically examining these popular images (e.g., commercials, documentaries, magazines) can help students to practically explore what stereotypes are, investigate how stereotypes affect those being portrayed, and interrogate the stereotypical ideas that they hold. Further, educators could challenge and balance stereotypical media images with alternatives such as diasporic films, documentaries, and self-authored works that offer different perspectives on African peoples and lifestyles. (p. 274-275)

Preparing and educating culturally competent student affairs professionals broadly has the potential of decreasing microaggressions towards African students (Awokoya, 2012; Harwood, et al., 2015; Okaplaoka \& Dillard, 2012; Stebleton, 2007; 2016).

It is also important that student affairs professionals who are responsible for teaching and sending American students to the African continent engage in anti-racist marketing. Since we know that U.S. college students have a very narrow perception of sub-Saharan African countries and values (Mou, 2014; Osunde, Tlou, \& Brown, 1996); it is extremely important for student affairs professionals frame and contextualize information in ways that help students unpack their experience before, during, and after their study abroad trip.

Misrepresentation of Africa through curriculum, study abroad promotional materials, and service learning trips does little to affirm the identity of IBAC. Research finds that images of Africa on campus promotional materials are consistent with poverty porn, which is media that exploits poverty in order to incite attention (Onyenekwu, Angeli, Pinto, \& Douglas, 2017).

\section{Pronounce Their Names}

Consistent with reports that find Chinese students value campus officials saying their name correctly (Fischer, 2015), research finds that Nigerian international students also appreciate when they are called by their 
preferred name (Onyenekwu, 2015). Students reported that student affairs professionals often mispronounced or shortened their names for convenience. For example, in one of my studies, an international graduate student described how he noticed that faculty and staff preferred using his Christian name in place of his Igbo name (Onyenekwu, 2015). Although the participant stressed to his academic department in person and on official school documents that he prefers to be called by his Igbo name, his attempt to be called by his Igbo name was undermined by professionals who may have thought that his name was too difficult to pronounce.

Mispronouncing names is not unusual; however, it is important that student affairs professionals make concerted efforts to say IBAC names correctly. In doing so, they show students that they respect and appreciate their culture. By ignoring and unapologetically mispronouncing African names, peers, faculty, and staff miss out on an opportunity to expand their understanding of Black African international students.

\section{Improve Financial Literacy Courses}

While many institutions have financial wellness centers, it is important for practitioners to have a well-versed understanding of the needs and challenges of IBAC. While all international students pay significantly higher tuition rates than their in-state tuition-receiving counterparts (Quaye \& Harper, 2014), IBAC end up being disproportionately impacted due to currency exchange. The U.S. dollar is substantially stronger than any currency coming from African countries. Given the difference in exchange rate, even high to middle class students experience challenges and socioeconomic jumping while they reside in the United States (Onyenekwu, 2015). It is vital that students are provided appropriate budgeting skills in order to manage their resources and the currency difference. Providing students with the most innovative and cost effective services such as international student friendly banks, grocery stores, and telecommunication providers is helpful.

Research literature finds that African students remit to their family while abroad (Obadare \& Adebanwi, 2009). As a result these students pay exorbitant fees to companies like Western Union for transferring money. It is imperative to keep in mind these fees when sharing money management strategies and resources on transferring money. To this end, students need help locating funding that will help alleviate their college expenses. Since research finds that finances are one of the top reasons students drop out of college, connecting them to resources and budgeting strategies are crucial to retention (Olbrecht, Romano, \& Tiegen, 2016). 
It is also imperative to understand and learn about students who are becoming naturalized citizens or have mixed citizenship statuses in their families. For example, naturalized citizens or students who have lived abroad may have trouble navigating financial aid systems such as FASFA. Therefore, being aware of the different citizenship statuses, and mixed status households will help in finding students who are in need of financial services, but are not traditional international students.

\section{Improve Job Placement and Career Services}

Research findings suggest that host institutions could do more to assist IBAC transition back to their home country. Respondents from my study on Nigerian returnees with foreign degrees reported that host institutions played little to no role in helping them secure employment in Nigeria. Rather, respondents explained that culturally centered social and professional networks, along with family connections, were most beneficial in resettlement and job placement in their home country. In addition, returnees relied heavily on family and extended family to support their integration, which included room and board.

While some interviewees in my studies shared that they learned about jobs through professional networks such as the National Society for Black Engineers (NSBE) and private companies, more participants expressed frustration with on campus career fairs. Employers oftentimes dismissed students' credentials and talents when they learned about an IBAC citizenship status. Sponsoring an international student and/or graduate is expensive and requires familiarity with processing work visas. Companies oftentimes try to avoid this complicated and costly process unless they are familiar with the procedure and possess the necessary resources to file for a work visa. In addition, respondents felt as though their host institutions lacked the compassion, awareness, and resources necessary to help with job placement in their home country or another country.

\section{CONCLUSION}

In sum, connecting IBAC within the wider context of supporting international students needs to be specific to combating anti-Black racism and other issues concerning the African diaspora. University personnel play an instrumental role in the identity construction of ethnically diverse Black populations (Onyenekwu, 2015; Patton et al., 2016). To this end, professional development is needed to help student affairs professionals better understand 
this population, particularly because their personal identities (i.e., African, Nigerian, Igbo, Yoruba, Hausa) do not fit neatly with how U.S. society perceives race and ethnic identity. This is important because understanding race and racial hierarchies prepares students to identify and navigate racism.

For students, navigating the advantages and disadvantage that come along with categories and labels can be emotionally taxing. Practitioners who understand the process in which an individual develops attitudes and beliefs associated with group membership will be better suited to advise and guide students as they make meaning of their experiences. In order to meet the diversity and internationalization initiatives of higher education, practitioners must pay attention to the increased diversity within the Black student population. In doing so, it is crucial to not limit the understandings of Black populations into a U.S. and non-U.S. Black international binary. Instead, the reality is that diversity (i.e., gender, ethnicity, generational status, nationality, birthplace) within the Black community is going unnoticed, and the university setting is a good space and opportunity to learn from people across the globe. Student affairs professionals should be prepared and culturally competent to help mitigate misunderstandings and facilitate intercultural and inclusive dialogue.

\section{REFERENCES}

Adichie, C. (2009). The danger of a single story. TED Talk. Retrieved from

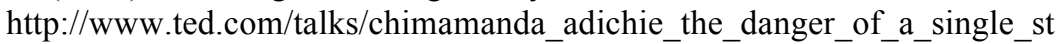
ory/transcript ?language $=$ en

Awokoya, J. (2012). Identity constructions and negotiations among 1.5 and second generation Nigerians: The impact of family, school, and peer contexts. Harvard Education Review, 255-283.

Baber, L. D. (2010). Beyond structural diversity: Centrality of campus 'place' in shaping experiences of African American students at predominately White institutions. TE Dancy II: Managing Diversity:(Re) Visioning Equity on College Campuses, 221-242.

Balogun, O. M. (2011). No necessary tradeoff: Context, life course, and social networks in the identity formation of second-generation Nigerians in the USA. Ethnicities, 1-31. doi: 10.1177/1468796811415759

Bennett, P. R., \& Lutz, A. (2009). How African American is the net black advantage? Differences in college attendance among immigrant blacks, native blacks, and whites. Sociology of Education, 82(1), 70-100.

Capps, R., McCabe, K., \& Fix, M. (2012), New streams: Black African migration to 
the United States, Migration Policy Institute, 1-26.

Fischer, K. (2015, May 27). Want to value Chinese students? Say their names right. The Chronicle of Higher Education. Retrieved from http:/www.chronicle.com/article/Want-to-Value-Your-Chinese/230399/

Fries-Britt, S., George Mwangi, C. A., \& Peralta, A. M. (2014). Learning race in a US Context: An emergent framework on the perceptions of race among foreign-born students of color. Journal of Diversity in Higher Education, $7(1), 1-13$.

George Mwangi, C. A. (2014). "Complicating Blackness: Black immigrants \& racial positioning in US higher education." Journal of Critical Thought and Praxis, 3(2), 1-27.

Harwood, S. A., Choi, S., Orozco Villicaña, M., Huntt, M. B., \& Mendenhall, R. (2015). Racial microaggressions at the University of Illinois at UrbanaChampaign: Voices of students of color in the classroom.

Hill, M. L. (2016). Nobody: Casualties of America's war on the vulnerable, from Ferguson to Flint and beyond. New York, NY: Simon and Schuster.

Institute of International Education, (2014). "Top 25 places of origin of international students, 2012/13- 2013/14." Open Doors Report on International Educational Exchange, Retrieved from http://www.iie.org/opendoors

Kent, M. (2007). Immigration and America's Black population, Population Bulletin, 62(4), 1-20.

Lee, J., \& Opio, T. (2011). Coming to America: Challenges and difficulties faced by African student athletes. Sport, Education and Society, 16(5), 629-644.

Lee, J. J., \& Rice, C. (2007). Welcome to America? International student perceptions of discrimination. Higher Education, 53(3), 381-409.

Massey, D. S., Mooney, M., Torres, K. C., \& Charles, C. Z. (2007). Black immigrants and black natives attending selective colleges and universities in the United States. American Journal of Education, 113(2), 243-271.

Massey, D. S., Mooney, M., Torres, K. C., \& Charles, C. Z. (2006). Black immigrants and black natives attending selective colleges and universities in the United States. American Journal of Education, 113(2), 243-271.

Mou, S. P. (2014). Of tribes, wars, and jungles: A study of college students' perception of Africa and Africans (Doctoral dissertation). Western Michigan University, Kalamazoo, MI.

Mujahid, A. [MujahidAngel]. (2017, March 28). Re: Nigerian students beaten in India. Retrieved https://m.facebook.com/story.php?story_fbid=929164883891686\&id=4075 70359384477\&_rdr

Museus, S. D. (2008). The role of ethnic student organizations in fostering African American and Asian American students' cultural adjustment and membership at predominantly White institutions. Journal of College Student Development, 49(6), 568-586. 
Obadare, E., \& Adebanwi, W. (2009). Transnational resource flow and the paradoxes of belonging: Redirecting the debate on transnationalism, remittances, state and citizenship in Africa. Review of African Political Economy, 36(122), 499-517.

Okpalaoka, C. L., \& Dillard, C. B. (2012). (Im) migrations, relations, and identities of African peoples: toward an endarkened transnational feminist praxis in education. The Journal of Educational Foundations, 26(1/2), 121- 142.

Olbrecht, A. M., Romano, C., \& Teigen, J. (2016). How money helps keep students in college: The relationship between family finances, merit-based aid, and retention in higher education. Journal of Student Financial Aid, 46(1), 2-10.

Onyenekwu, I. U. C. (2015). "I am not beneath you because I am from a different continent, I am also like you!": Nigerian college students make meaning of racial and ethnic identity at a predominantly white institution (Doctoral dissertation, University of Illinois at Urbana-Champaign).

Onyenekwu, I., Angeli, J. M., Pinto, R., \& Douglas, T. R. (2017).

(Mis)representation among U.S. study abroad programs traveling to the African continent: A critical content analysis of a Teach Abroad program. Frontiers: The Interdisciplinary Journal of Study Abroad, 29(1), 68-84.

Osunde, E., Tlou, J., \& Brown, N. (1996). Persisting and common stereotypes in U.S. students' knowledge of Africa: A study of pre-service social studies teachers. Social Studies, 87(3), 119-124.

Patton, L. D., Renn, K. A., Guido, F. M., \& Quaye, S. J. (2016). Student development in college: Theory, research, and practice. San Francisco, CA: John Wiley \& Sons.

Pierre, J. (2004) Black immigrants in the United States and the "cultural narratives" of ethnicity. Identities: Global Studies in Culture and Power, 11(2), 141170.

Poon, O., Squire, D., Kodama, C., Byrd, A., Chan, J., Manzano, L., ... \& Bishundat, D. (2016). A critical review of the model minority myth in selected literature on Asian Americans and Pacific Islanders in higher education. Review of Educational Research, 86(2), 469-502.

Quaye, S. J., \& Harper, S. R. (2014). Student engagement in higher education: Theoretical perspectives and practical approaches for diverse populations. New York: Routledge.

Reynolds, A. L. (2009). Helping college students: Developing essential support skills for student affairs practice San Francisco, CA: Jossey - Bass.

Rimer, S., \& Arenson, K. W. (2004). Top colleges take more blacks, but which ones? New York Times, 24, A1.

Unah, L. (March 1, 2017). "Who is South Africa to humiliate Nigeria?". African Arguments. Retrieved from http://africanarguments.org/2017/03/01/who-issouth-africa-to-humiliate-nigeria/

Stebleton, M. J. (2007). Career counseling with African immigrant college students: 
Theoretical approaches and implications for practice. The Career Development Quarterly, 55(4), 290-312.

Stebleton, M. J., \& Aleixo, M. B. (2016). Black African immigrant college students' perceptions of belonging at a predominately White institution. Journal of The First-Year Experience \& Students in Transition, 28(1), 89107.

Steeves, D. (2016). The social impact of FinTech in Nigeria. The FinTech Book: The Financial Technology Handbook for Investors, Entrepreneurs and Visionaries, 78-80. doi: 10.1002/9781119218906.ch21

$\mathrm{Wu}, \mathrm{H}$. (2017, March 31). African students hospitalized in roving mob attacks in India. CNN. Retrieved from http://www.cnn.com/2017/03/29/asia/indiaafrica-kenya-nigeria-attacks/

IFEYINWA ONYENEKWU, PhD, is an Assistant Professor of Practice in the College Student Affairs program in the Graduate School of Education at Rutgers The State University of New Jersey. Her major research interests lie in the area of internationalization and globalization of higher education, ethnically diverse Black collegians, and equity and access in P-20 education pipeline.

Email: ifeyinwa.onyenekwu@gse.rutgers.edu 